\title{
SISTEM SEKOLAH BERASRAMA (BOARDING SCHOOL) DALAM MEMBENTUK KARAKTER DISIPLIN DI MAN 1 KOLAKA
}

\author{
Oleh: Muh Miftahul Nurul Reskiawan', Andi Agustang \\ ${ }^{12}$ Program Studi pendidikan Sosiologi Fakultas Ilmu Sosial dan Hukum \\ Universitas Negeri Makassar \\ Email: muhmiftahulo@gmail.com ${ }^{1}$, andi.agustang@unm.ac.id ${ }^{2}$.
}

\begin{abstract}
Abstrak
Penelitian ini bertujuan untuk mengetahui 1) proses pembinaan pada sistem sekolah berasrama (boarding school) dalam membentuk karakter disiplin siswa di MAN 1 Kolaka, 2) kendala yang di hadapi siswa dan guru dalam proses sekolah berasrama, dan 3) hasil penerapan tata tertib sistem sekolah berasrama (boarding school) dalam membentuk karakter disiplin di MAN 1 Kolaka. Jenis penelitian ini merupakan jenis penelitian kualitatif dengan pendekatan deskriptif. Jumlah informan pada penelitian ini sebanyak 12 orang yang ditentukan melalui teknik purposive sampling dengan kriteria informan yaitu: 1) Kepala Asrama Man 1 Kolaka, 2) Pembina Asrama Man 1 Kolaka, dan 3) Siswa yang mengikuti sekolah asrama Man 1 Kolaka. Teknik pengumpulan data yang dilakukan yaitu observasi, wawancara, dan dokumentasi. Teknik pengabsahan data menggunakan member check. Teknik analisis data yaitu menggunakan kondensasi data, penyajian data dan penarikan kesimpulan. Hasil Penelitian menunjukkan bahwa: 1) Penerapan sistem sekolah berasrama yang ada di MAN 1 Kolaka yaitu: a) menekan aturan dalam setiap rutinitas siswa, b) membangun kedekatan dengan komunikasi yang baik antara pembina dengan siswa, c) memilki jam pelajaran tambahan. 2) Kendala yang di hadapi dalam proses pelaksanaan sistem berasrama di MAN 1 Kolaka dalam membentuk karakter disiplin yaitu: a) kendala yang di hadapi pembina ialah kurang tenaga pendidik di dalam asrama, b) kendala yang di hadapi siswa yaitu tidak adanya ruang privasi dan merasa jenuh. 3) Hasil penerapan tata tertib dalam membentuk karakter displin di MAN 1 Kolaka yaitu: a) berkurangnya siswa yang melanggar aturan dan b) meningkatnya kedisiplinan..
\end{abstract}

Kata Kunci: Sistem, Sekolah berasrama, Disiplin

\section{PENDAHULUAN}

Pendidikan merupakan fenomena fundamental yang terjadi dalam kehidupan manusia,sehingga dapat dikatakan dimana ada kehidupan manusia, bagaimanapun juga disitu pasti ada pendidikan meskipun masih dalam bentuk yang paling sederhana. Saat ini dunia telah memberikan pengaruh globalisasi yang cukup besar dan memberikan berbagai dampak yang berbeda pada setiap kehidupan anak manusia. Dalam hala ini karakter bagi karakter bagi setiap manusia adalah sebuah kewajiban yang harus dilakukan terus menerus tanpa henti baik melalui pembinaan, membiasaan dan hal-hal 
yang dapat meningkatkan perbaikan karakter seseorang (Awaru, 2017). Moralitas merupakan faktor yang esensial. Pesatnya perkembangan ilmu teknologi yang terjadi memberi perubahan terhadap cara pandang dan berfikir masyarakat. (Irawati \& Susetyo, 2017) Di dalam Undang-Undang Nomor 20 Tahun 2003. tentang Sistem Pendidikan Nasional Bab 1 Pasal 1 dikemukakan, bahwa: Pendidikan adalah usaha sadar dan terencana untuk mewujudkan suasana belajar dan proses belajar agar peserta didik secara aktif mengembangkan potensi dirinya untuk memiliki kekuatan spiritual keagamaan, pengendalian diri, kepribadian, kecerdasan, ahlak mulia, serta keterampilan yang di perlukan dirinya, masyarakat, bangsa dan negara.

Perubahan zaman yang begitu cepat menuntut manusia agar dapat bersaing pada semua aspek kehidupan. Utamanya dalam aspek bidang pendidikan. Ada tiga jalur pendidikan, yaitu pendidikan formal, nonformal, dan informal. Pendidikan formal adalah kegiatan yang bersifat sistematis, bertingkat atau berjenjang. Pendidikan formal dimulai dari sekolah dasar sampai dengan perguruan tinggi atau yang setaraf dengannya. Pendidikan non-formal adalah pendidikan yang didapatkan di luar sistem persekolahan yang dilakukan secara mandiri yang sengaja dilakukan untuk menambah wawasan yang tidak didapatkan dalam ruang lingkup sekolah. Hidayati,dkk (2015) Pendidikan informal adalah proses belajar yang berlangsung sepanjang usia sehingga setiap orang memperoleh nilai, sikap, keterampilan dan pengetahuan yang didapatkan melalui pengalaman hidup sehari hari. Pendidikan merupakan salah satu faktor yang mempengaruhi terhadap perkembangan bangsa dan peradaban bangsa yang ada di dalamnya. Pendidikan merupakan pondasi utama menuju kehidupan yang lebih baik. Untuk negara berkembang seperti negara kita ini, pendidikan merupakan kebutuhan mutlak yang harus lebih di prioritaskan dan ditingkatkan. Setiap jenjang akan dilalui oleh setiap siswa seiring dengan hal tersebut tentu siswa akan mengalami perubahan dan perkembangan dari segi jasmani maupun rohani. Kehidupan siswa yang bersifat dinamis pada masa perkembangan tentu mengharuskan pendidikan yang diberikan kepada mereka juga harus disesuaikan dengan kondisi kejiwaan mereka. Sekolah Menegah Atas (SMA) pada jenjang ini siswa sedang mengalami fase peralihan dari remaja ke dewasa dalam hal ini pencarian jati diri. Pada fase ini, pendidik harus pandai dalam memberi bimbingan agar seorang siwa mampu mengontrol dirinya kerena pada fase tahap peralihan siswa sangat rentang dengan pengaruh-pengaruh negatif. Jadi jika identitas diri seseorang siswa tidak kuat dari awal maka mereka akan sangat mudah terpengaruh hal negatif yang akan menghambat masa depan mereka.(Hartini, 2017)

Siswa yang nantinya akan menjadi generasi penerus yang seharusnya memiliki karakter yang baik, tapi pada realitanya masih banyak kita jumpai siswa yang melakukan penyimpangan-penyimpangan atau tindakan negatif pada dunia pendidikan. Identitas seorang siswa di pengaruhi oleh karakter yang kuat. Seharusnya sekolah bukan hanya berperan sebagai fasilitator dalam proses pembelajaran saja, melainkan sekolah juga bereperan dalam proses pembentukan karakter siswa. Karakter 
sangatlah penting sebab karakter adalah penentu perjalanan sebuah bangsa. Melalui pendidikan karakter ini diharapkan dapat mendorong siswa untuk menjadi manusia yang berkepribadian yang baik dan berintelektual, sebagaimana tujuan dan fungsi pendidikan nasional. Penerapan pendidikan karakter ini mutlak sangat diperlukan bukan hanya ruang lingkup sekolah saja, tapi di rumah dan di lingkungan sosial.

Kedispilinan merupakan contoh karakter yang mampu membuat orang menilai kita. Kedispilinan merupakan karakter taat pada suatu ketentuan yang telah disepakati bersama, biasanya kedisplinan berkaitan dengan waktu serta peraturan. Thomas Gordon dalam (Ramlafatma et al., 2021) Farhana dan Markum 2019) disiplin adalah prilaku dan tata tertib yang sesuai dengan peraturan dan ketetapan, atau prilaku yang di peroleh dari pelatihan yang dilakukan secara terus menerus. Namun kedisplinan merupakan karakter yang sulit terbentuk pada masyarakat Indonesia, terbukti pada setiap kegiatan selalu saja ada keterlambatan waktu dalam menjalankannya seperti terlambat upacara, lambat masuk jam pembelajaran, dan lambat mengerjakan tugas dan sebagainya. Walaupun karakter disiplin terasa sulit dijalankan kerena pola kebiasaan yang berbeda, masih ada cara lain untuk dapat membentuk karakter disiplin. Salah satunya adalah dengan adanya sekolah-sekolah yang mengadakan sistem sekolah berasrama atau sering disebut dengan (boarding school). Istilah asrama memang bukan hal yang asing di ranah pendidikan Indonesia. Pondok pesantren merupakan sekolah yang sejak dulu menerapkan sistem berasrama. Boarding school banyak dijadikan acuan dalam pendidikan karakter pada setiap sekolah. Sekolah berupaya memperkenalkan visi dan misinya yaitu tidak hanya mendidik siswa didalam kelas, tetapi juga dengan membantu para siswa agar dapat berorientasi lebih baik.

MAN 1 Kolaka merupakan salah satu sekolah yang menerapkan sistem sekolah berasrama (boarding school). Sekolah ini merupakan sekolah umum negeri yang pertama kalinya di Kabupaten Kolaka yang menerapkan sistem berasrama. Susiyani (2017) Sistem sekolah berasrama adalah tempat siswa mendapatkan pengetahuan lebih tentang nilai-nilai moralitas kerena sistem boarding school memiliki komitmen untuk mengujudkan pendidikan karakter yang meliputi kedispilinan, kemandirian, ketaatan atau kepatuhan pada segala aturan perilaku moral, dan tanggung jawab. Peran pembina asrama untuk membimbing siswa siswinya yang tinggal di asrama sangatlah penting, pembina diharapkan dapat menanamkan nilai-nilai positif baik dalam segi religius maupun secara umum dengan cara memberikan teladan pada semua peserta didik yang ada MAN 1 Kolaka.

Sistem Boarding school sangat efektif dalam pendidikan karakter kedisplinan. Sebab seluruh aktifitas telah diatur dengan jelas dari waktu ke waktu dengan syarat atau ketentuan yang harus dijalankan dengan muatan nilai-nilai moralitas. Karakter tidak terbentuk secara instan,tetapi harus dilatih dengan serius dan terus menerus agar mencapai bentuk karakter yang ideal dalam hal ini kedisplinan. MAN 1 Kolaka adalah sekolah yang berlabel islam dan memiliki program Boarding school (asrama) biasanya memiliki kurikulum pelajaran islam yang lengkap. Sekolah tersebut merupakan tempat 
belajar yang mendukung pembentukan karakter. Disebut membentuk karakter displin dan mandiri, sebab dalam asrama siswa dilatih harus mengerjakan semua kebutuhanya sesuai dengan waktu yang ditetapkan oleh sekolah.

Berdasarkan observasi awal, penulis menemukan beberapa hal menarik salah satunya perbedaan kebiasaan pada setiap siswa, tetapi mengharuskan siswa dapat beradaptasi pada kebiasaan barunya. terutama pada faktor kedisplinan siswa.

\section{METODE PENELITIAN}

Jenis penelitian yang digunakan dalam penelitian ini adalah penelitian kualitatif dengan menggunakan pendekatan deskripstif yang memusatkan perhatian dengan tujuan untuk mengungkapkan penerapan sistem sekolah berasrama (boarding school) dalam membentuk karakter disiplin siswa, kendala yang dihadapi siswa dan pembina asrama dalam pelaksanaan sekolah berasrama (boarding school) dalam membentuk karakter disiplin siswa, dan hasil penerapan tata tertib sistem sekolah berasrama (boarding school) dalam membentuk karakter displin siswa di MAN 1 Kolaka. Dalam penelitian ini penulis mengambil lokasi penelitian di MAN 1 Kolaka. Adapun tahaptahap yang digunakan dalam penelitian ini secara garis besar yaitu tahap pra penelitian, tahap pelaksanaan penelitian, dan tahap akhir. Sumber data yang digunakan yaitu sumber data primer dan sumber data sekunder. Jumlah informan sebanyak 12 orang yang dipilih berdasarkan teknik purposive sampling. Teknik pengumpulan data dengan metode penelitian kepustakaan dan penelitian lapangan yang terdiri dari observasi, wawancara dan dokumentasi. Pengecekan keabsahan data menggunakan member check (Agustang. A, 2011). Dengan teknik analisis data meliputi pengumpulan data, reduksi data, penyajian data dan penarikan kesimpulan.

\section{PEMBAHASAN}

\section{Penerapan Sistem Sekolah Berasrama (Boarding School) dalam Membentuk Karakter Disiplin Siswa di MAN 1 Kolaka.}

Sistem pada dasarnya adalah gabungan dari elemen-elemen (objek, manusia, informasi dan sebagainya) yang saling di hubungkan oleh suatu proses atau skruktur, dan berfungsi sebagai kesatuan organisatoris dalam usaha menghasilkan sesuatu. Sekolah Berasrama (Boarding School) adalah sistem yang di realisasikan MAN 1 Kolaka dalam upaya untuk menghasilkan output peserta didik yang memiliki karakter dan ahlak yang lebih baik, dalam hal ini lebih dispesifikkan pada karakter disiplin.

Disiplin adalah kesadaran untuk melakukan sesuatu dengan tertib mengikuti norma sosial yang ada. Atau bisa juga di artikan bahwa disiplin itu adalah kepatuhan terhadap peraturan yang telah ada. MAN 1 Kolaka merupakan Sekolah Negeri pertama yang ada di Kabupaten Kolaka yang menerapkan Sistem Berasrama (Boarding School). Dalam hal menanamkan karakter disiplin boarding school bisa menjadi solusi untuk pendidikan karakter bagi peserta didik untuk menjadi lebih baik, Kerena proses dari karantina yang dilakukan terbilang sangat baik karena di dalam asrama aturan dan tata 
tertib sangat di tekankan. Meski kita tahu bahwa tidak semua anak memiliki kepribadian yang sama, di MAN 1 Kolaka juga masih ada sebagian kecil yang belum mencapai target kedisplinan yang maximal akan tetapi itu bukan ahir dari upaya yang dilakukan pihak penyelenggara boarding school dalam menanamkan karakter disiplin. Pembina akan terus berupaya dan terus melakukan pembiasaan dan pendekatan terhadap setiap peserta didik dengan menjalin ikatan emosional terhadap peserta didik hingga muncul kesadaran pada diri peserta didik itu sendiri.

Sesuai dengan hasil penelitian Pembentukan karakter disiplin itu bisa melalui pembiasaan dan penyadaran terhadap pentingnya kedisplinan bagi kehidupan sehari hari. (Agustang, A. 2021) mengatakan bahwa disiplin merupakan suatu kemampuan individu yang terjadi di sebabkan kerena atas dasar kesadaran dan kerelaan diri maupun oleh pemerintah atau tuntutan yang lain. Peran sistem boarding school pada peserta didik sangat berpengaruh, meski awalnya akan terasa sulit bagi sebagian peserta didik tetapi dengan terbiasa mengikuti aturan dan rentetan kegiatan rutinitas pada asrama dimulai dari bangun tidur hingga waktu tidur kembali maka tentu peserta didik ahirnya akan terbiasa sehingga perlahan kedisplinan melekat pada diri mereka.

Teori Skruktural Fungsional Robert King Merton tentang pembagian fungsi manifest dan fungsi laten erat kaitanya dengan penelitian ini. Fungsi manifes adalah tujuan atau penjelasan aktor dalam skruktur yang berguna untuk menilai atau menjelaskan fakta sosial, kelompok atau pristiwa (dalam arti sederhananya adalah fungsi yang di kehendaki tidak dimaksudkan) (Wirawan, 2012). Sedangkan yang di maksud fungsi laten adalah fungsi yang tidak di harapkan atau tak di khendaki.

Berdasarkan hasil penelitian dapat di jelaskan bahwa MAN 1 Kolaka yang menerapkan sistem boarding school memiliki fungsi manifest dan laten. Implementasi dari Sekolah Berasrama ( Boarding School ) di MAN 1 Kolaka memberikan banyak dampak yang baik bagi peserta didik, Seperti dalam ilmu pengetahuan dan keagamaan serta pendidikan karakter kemandirian dan kedisiplinan tidak terlepas didalamnya. Di samping fungsi manifest yang memilki banyak sisi positif bagi peserta didik, Tentu terdapat juga fungsi laten di dalamnya dimana banyaknya aturan yang ada akan membuat peserta didik merasa tidak bebas yang akan tentu menimbulkan tekanan batin tersendiri bagi sebagian peserta didik yang secara pysikologi tidak dapat beradaptasi pada lingkungan tersebut.

Implementasi dari suatu sistem tidak terlepas dari yang namanya kelebihan dan kekurangan seperti hal nya boarding school, ada banyak manfaat positif yang di dapatkan akan tetapi tak dapat di pungkiri juga bahwa ada dampak negatif yang juga dirasakan oleh peserta didik (Agustang, 2021a) (Henry, 2013). Terlepas dari kelebihan dan kekurangan yang didapatkan tentu dalam penerapan boarding school sistem suatu komponen yang ada di dalamnya saling mempengaruhi satu sama lain.

Talcott Parson (dalam Makmur 2017) (Syukur, 2018) dimana teori setruktural fungsional merupakan salah satu paham atau prespektif dalam sosiologi yang memandang bahwa masyarakat sebagai suatu sistem yang terdiri dari bagian- bagian 
saling berhubungan satu sama lain dan komponen satu tidak dapat berfungsi tanpa ada komponen yang lain. Apabila dikaitkan dengan teori skruktural fungsional oleh Talcott Parson dalam skema AGIL, Sistem Sekolah Berasrama (Boarding School) dalam membentuk karakter disiplin pada siswa merupakan suatu komponen yang saling berkesinambungan dalam hal ini proses pembinaan dan kegiatan yang ada di asrama berjalan sebagaimana mestinya dan tidak menghambat komponen lain dalam hal ini proses belajar mengajar di dalam kelas. Dengan keterkaitan yang saling mempengaruhi dari masing-masing komponen suatu sistem pendidikan di sekolah, seperti halnya kepala sekolah, guru, pembina, murid, sarana, prasarana, kurikulum. Serta kegiatan lain yang saling berkaitan yang akan menunjang keberhasilan dari sistem itu sendiri ataupun sesuai harapan dan tujuan yang di inginkan (Suardi et al., 2020)

Berdasarkan hasil penlitian dapat dijelaskan bahwa, dalam proses pembinaan yang di lakukan boarding school yang ada di MAN 1 Kolaka pada dasarnya adalah suatu upaya internalisasi nilai-nilai yang bersumber dari budaya luhur bangsa indonesia sehingga menjadi sitem nilai dalam diri peserta didik. Sistem nilai yang tertanam tersebut akan melandasi sikap dan prilaku dalam kesehariananya yang kemudian menjadi sebuah kebiasaaan dan secara konsisten tertanam di dalam alam bawasadar pada setiap peserta didik dalam menghadapi setiap situasi yang terjadi. Hal tersebut merupakan salah satu faktor pembentukan karakter. (Suardi et al., 2021a) kebiasaan yaitu salah satu faktor yang penting dalam tingkah laku manusia, kerena sikap dan prilaku yang menjadi karakter sangat erat sekali dengan kebiasaan, yang dimaksud disini adalah perbuatan yang selalu di ulang ulang sehingga mudah untuk dikerjakan.

Pelaksanaan dan pembinaan serta penerapan pembentukan karakter di MAN 1 Kolaka di laksanakan 24 jam baik ketika berada di sekolah maupun asrama, dan libur di berikan ke pada peserta didik di ahir pekan selama 1 hari yakni dimulai dari sabtu sore hingga minggu siang peserta didik harus kembali kedalam asrama. Penerapan boarding school yang ada di MAN 1 Kolaka harus di dukung oleh semua elemen-elemen yang terkait seperti guru, pembina, peserta didik, sarana, dan prasrana yang akan menunjang keberhasilan dari penerapan sistem tersebut. Proses pembentukan karakter di perlukan beberapa metode baik itu pendapingan memalui pendekatan kepada siswa dalam menjalin ikatan emosional ataupun pengembangan proses pembelajaran di dalam kelas, kegiatan di sekolah dan asrama ataupun dalam keseharaian peserta didik yang terkait dengan pembentukan karakter, dalam hal ini di khususkan dalam karakter disiplin (Mithhar \& Agustang, 2021).

Dengan diterapkannya pendampingan ataupun proses karantina yang ada dalam sistem asrama di MAN 1 Kolaka pendidikan ataupun pembentukan karakter akan menjadi lebih mudah kerena dalam proses ini membantu setiap peserta didik untuk menerapkan prilaku yang baik di dalam sekolah maupun diluar sekolah.

Berdasarkan hasil penelitian dapat di jelaskan bahwa, penerapan sistem asrama boarding school melalui bimbingan dan juga serangkaian kegiatan-kegiataan yang ada di dalam asrama di nilai sangat baik dalam membentuk karakter disiplin. Sebab pendampingan secara langsung yang dilakukan secara terus menurus kepada setiap peserta didik dapat menjadikan peserta didik menjadi lebih terarah dan memilki ahlak 
dan karakter yang lebih baik kedepanya sesuai dengan harapan dari tujuan boarding school di MAN 1 kolaka.

Pada dasarnya bisa kerena biasa, begitupun peserta didik MAN 1 Kolaka yang mengikuti program boarding school kembali lagi cepat lambatnya tujuan itu tergantung ke peserta didik itu sendiri dalam kemampuan beradaptasi dan keinginan yang kuat untuk berubah sebab sebagus apapun sebuah sistem dalam mendisplinkan jika tak memiliki niat untuk berubah maka hasilnya akan sia-sia dan sama saja.

\section{Kendala Yang di Hadapi Dalam Proses Pelaksanaan Sekolah Berasrama (Boarding School) di MAN 1 Kolaka.}

Penerapan suatu program atau kebijakan dari sebuah lembaga pendidikan memiliki sisi positif dan negatif terhadap pihak-pihak yang terlibat dalam pelaksanaan atau kebijakan tersebut (Agustang, 2021b) dalam hal ini adalah tenaga pendidik dan peserta didik dalam menjalakan sistem sekolah asrama (boarding school) dalam penerapan sistem asrama yang memiliki manfaat tapi tidak menutup kemungkinan juga masih memiliki kekurangan.

Berdasarkan hasil penelitian yang dilakukan, dapat dijelaskan bahwa penerapan boarding school yang ada di MAN 1 Kolaka sangat baik dalam pembentukan karakter bagi peserta didik. Kerena dalam setiap kegiatan yang di lakukan peserta didik selalu dalam pengawasan dan bimbingan oleh pembina asrama selama 24 jam yang memiliki tujuan untuk membentuk karakter yang baik bagi setiap peserta didik.

Sebagaimana yang dimaksud Kementrian Pendidikan Nasional dalam (Agustang et al., 2021) "pendidikan karakter merupakan pendidikan nilai, pendidikan budi pekerti, pendidikan moral, pendidikan watak yang bertujuan mengembangkan kemampuan siswa untuk memberikan keputusan baik-buruk memelihara apa yang baik dan mewujudkan kebaikan itu dalam kehidupan sehari-hari dengan sepenih hati”. Dalam membentuk karakter diperlukan sumber daya yang berkualitas, seperti peraturan pendidikan yang baik, tenaga pendidik yang profesional, sarana dan prasarana yang memadai serta kegiatan dan lingkungan yang mendukung. Terlepas dari kelebihan yang di dapatkan dalam menjalankan sistem boarding school tentu terdapat beberapa kendala yang di hadapipada saat proses pelaksaan itu sendiri. Maka peneliti membaginya menjadi dua bagian yakni kendala yang di hadapi oleh tenaga pendidik dan kendala yang di hadapi oleh peserta didik.

Berdasarkan hasil penelitian, dapat dijelaskan bahwa kendala yang di hadapi oleh tenaga pendidik antara lain kurangnya jumlah tenaga pendidik yang ada di dalam ruang lingkup asrama di sebabkan oleh ada beberapa tenaga pendidik yang dipindah tugaskan ke tempat lain yang membuat pembina asrama sering kewalahan dalam menjalankan kegiatan-kegitan yang ada di asrama. Berbeda dengan kendala yang di hadapi oleh tenaga pendidik, berdasarkan hasil wawancara dengan beberapa peserta didik memilki beberapa kendala di antaranya yaitu ketatnya aturan yang ada membuat sebagian peserta didik merasa tertekan dan juga beberapa peserta didik merasa jenuh yang di sebabkan kurang nya hiburan di asrama (Suardi et al., 2021a). 


\section{Bagaimana Hasil Penerapan Tata tertib Sistem Sekolah Berasrama (Boarding School) dalam Membentuk Karakter Displin Siswa di MAN 1 Kolaka}

Sekolah berasrama (boarding school) merupakan lembaga sekolah dimana di dalamanya terdapat asrama sebagai tempat tinggal para peserta didik selama masa studi. Di dalam kehidupan asrama mempunyai beberapa rentetan kegiatan pembelajaran keagamaan sebagaimana di pesantren. Tata tertib di MAN 1 Kolaka hampir sama dengan di sekolah boarding school pada umumnya yang bertujuan menciptakan output yang berkualitas (Andi Agustang et al., 2021).

MAN 1 Kolaka memiliki aturan dan tata tertib yang baru dan terbilang efesien dan di nilai mampu dalam mendisplinkan peserta didik, dilihat dari beberapa tahun belakangan jumlah peserta didik yang melanggar mulai berkurang, hal ini di kerenakan aturan yang ada di MAN 1 Kolaka sangat di tekankan pada setiap peserta didik. Dalam mencapai tujuan dari pada boarding school itu sendiri diperlukan konsistensi dalam menjalankan sebuah sistem dan juga pengelolahan yang baik sangat di perlukan, Menejemen kegiatan dan juga aturan harus dibuat seefektif mungkin untuk mencapai tujuan dari sistem itu sendiri.

Berdasarkan hasil penelitian lakukan, MAN 1 kolaka memiliki aturan yang begitu ketat namun di balik itu juga mememiliki manfaat yang sangat baik dalam hal mendisplinkan para peserta didik, dimana aturan tersebut berlaku bagi setiap peserta didik tanpa tebang pilih. MAN 1 Kolaka memiliki beberapa aturan yang dimana di setiap pelanggaran yang dilakukan oleh peserta didik bersistem poin pada setiap pelanggaranya. Setiap pelanggaran yang dilakukan memilki poinnya tersendiri dimulai dari paling kecil yaitu kerapian, ketepatan waktu, dan sebagainya. Semua aturan memiliki poin, dan apabila peserta didik memiliki pelanggaran dan poin yang di dapatkan mencapai 100 poin, maka sanksi yang harus di terima adalah peringatan tegas dimana pemanggilan kepada orangtua/wali peserta didik yang kemudian di lanjutkan dengan membuat surat pernyataan tertulis oleh peserta didik itu sendiri. Dalam pernyataan tersebut apabila di dapati peserta didik masih melakukan ataupun melanggar aturan sekali lagi maka peserta didik bersedia untuk di keluarkan dari sekolah (Suardi et al., 2021b).

\section{PENUTUP}

Berdasarkan hasil penelitian yang dilakukan oleh penulis, dapat ditarik kesimpulan sebagai berikut: 1) Penerapan sistem sekolah berasrama yang ada di MAN 1 Kolaka yaitu a) menekankan aturan di setiap rutinitas peserta didik, b) membangun kedekatan dengan komunikasi yang baik antara pembina dengan peserta didik, c) pelajaran tambahan. 2) Kendala yang di hadapi dalam proses pelaksanaan sistem berasrama di MAN 1 Kolaka yaitu dalam membentuk karakter disiplin yaitu a) kendala 
yang di hadapi pembina ialah kurang tenaga pendidik di dalam asrama, b) kendala yang di hadapi siswa ialah tidak adanya ruang privasi dan merasa jenuh. 3)Hasil penerapan tata tertib dalam membentuk karakter displin di MAN 1 Kolaka yaitu: a)Berkurangnya siswa yang melanggar aturan, b)Meningkatnya kedisiplinan.

\section{DAFTAR PUSTAKA}

Agustang. A. (2011). FILOSOFI RESEARCH DALAM UPAYA PENGEMBANGAN ILMU.

Agustang, A. (2021a). Filosofi Research Dalam Upaya Pengembangan Ilmu. OSF Preprints.

Agustang, A., \& Oruh, S. (2021). KESEJAHTERAAN PSIKOLOGIS (studi Pada Dewasa Madya Yang Belum Menikah Di Kota Makassar).

Agustang, A. (2021b). \{INTERAKSI $\}$ SSOSIAL $\}\{$ KOMUNITAS $\}\{L O K A L\}\{D E N G A N\}$ $\{$ PENDATANG $\}$ DAN $\}$ PPERUBAHAN\} \{STRUKTUR $\}$ KOMUNITAS $\}$ LLOKAL\} (Studi pada Masyarakat Majemuk di Kawasan Industri Makassar). https://doi.org/10.31219/osf.io/pw5xr

Agustang, A., Suardi, S., Putra, A. D. M., \& Oruh, S. (2021). Pemberdayaan Guru Mata Pelajaran Sosiologi Melalui Literasi Digital Berbasis Quick Response Code di Kecamatan Bissappu Kabupaten Bantaeng. Abdi: Jurnal Pengabdian Dan Pemberdayaan Masyarakat, 3(2), 175-188. https://doi.org/10.24036/abdi.v3i2.120

Andi Agustang, Suardi Suardi, Andi Dody May Putra Agustang, \& Shermina Oruh. (2021). Pemberdayaan Guru Mata Pelajaran Sosiologi Melalui Literasi Digital Berbasis Quick Response Code di Kecamatan Bissappu Kabupaten Bantaeng. ABDI: Jurnal Pengabdian Dan Pemberdayaan Masyarakat, Vol. 3(2), 175-188.

Mithhar, M., \& Agustang, A. (2021). Distorsi Pendidikan Karakter Siswa Dalam Pendidikan Jarak Jauh Pada Era Pandemi Covid-19 Di Kabupaten Majene, Indonesia. Seminar Nasional LP2M UNM.

Ramlafatma, R., Oruh, S., \& Agustang, A. (2021). Efektivitas Pendidikan Moral Dalam Pembentukan Karakter Siswa Di TK Islam Terpadu Asa Sumbawa. Jurnal Ilmiah Mandala Education, 7(4).

Suardi, Agustang, A., \& Jumadi. (2021a). DOMINATION OF THE POWER OF QUALITY AND QUANTITY OF STATE SCHOOL EDUCATION AGAINST PRIVATE SCHOOLS AS FACTORS CAUSING SYMBOLIC VIOLENCE OF STUDENTS IN BANTAENG DISTRICT. PROCEEDING 1st INTERNATIONAL CONFERENCE (On Health, Education, and Computer Science Technology), 1(pertama), 246-259.

Suardi, Agustang, A., \& Jumadi. (2020). THE SYMBOLIC VIOLENCE TOWARDS PRIVATE SCHOOL STUDENTS THROUGH THE FRAME STEREOTYPE IN BANTAENG DISTRICT OF INDONESIA. The International Conference on Innovations in Social Sciences and Education, 578-588.

Suardi, S., Agustang, A., \& Jumadi, J. (2021b). Dominasi Sekolah Negeri Terhadap Sekolah Swasta Sebagai Penyebab Kekerasan Simbolik Terhadap Siswa Sekolah Swasta. Jurnal Ilmiah Muqoddimah: Jurnal Ilmu Sosial, Politik Dan Hummanioramaniora, 5(2). 